\title{
Evaluating Sexual Harassment against Female Workers in Higher Institutions in Anambra State, Nigeria
}

Elizabeth Ifeoma Anierobi, Chukwuemeka E. Etodike, Vivian Ngozi Nwogbo, Nkechi Uzochukwu Okeke \& Mary Nneka Nwikpo

To Link this Article: http://dx.doi.org/10.6007/IJARBSS/v11-i2/8687 DOI:10.6007/IJARBSS/v11-i2/8687

Received: 29 December 2020, Revised: 25 January 2021, Accepted: 05 February 2021

Published Online: 15 February 2021

In-Text Citation: (Anierobi et al., 2021)

To Cite this Article: Anierobi, E. I., Etodike, C. E., Nwogbo, V. N., Okeke, N. U., \& Nwikpo, M. N. (2021).

Evaluating Sexual Harassment against Female Workers in Higher Institutions in Anambra State, Nigeria. International Journal of Academic Research in Business and Social Sciences, 11(2), 265-278.

Copyright: @ 2021 The Author(s)

Published by Human Resource Management Academic Research Society (www.hrmars.com)

This article is published under the Creative Commons Attribution (CC BY 4.0) license. Anyone may reproduce, distribute, translate and create derivative works of this article (for both commercial and non-commercial purposes), subject to full attribution to the original publication and authors. The full terms of this license may be seen at: http://creativecommons.org/licences/by/4.0/legalcode

Vol. 11, No. 2, 2021, Pg. 265 - 278

Full Terms \& Conditions of access and use can be found at http://hrmars.com/index.php/pages/detail/publication-ethics 


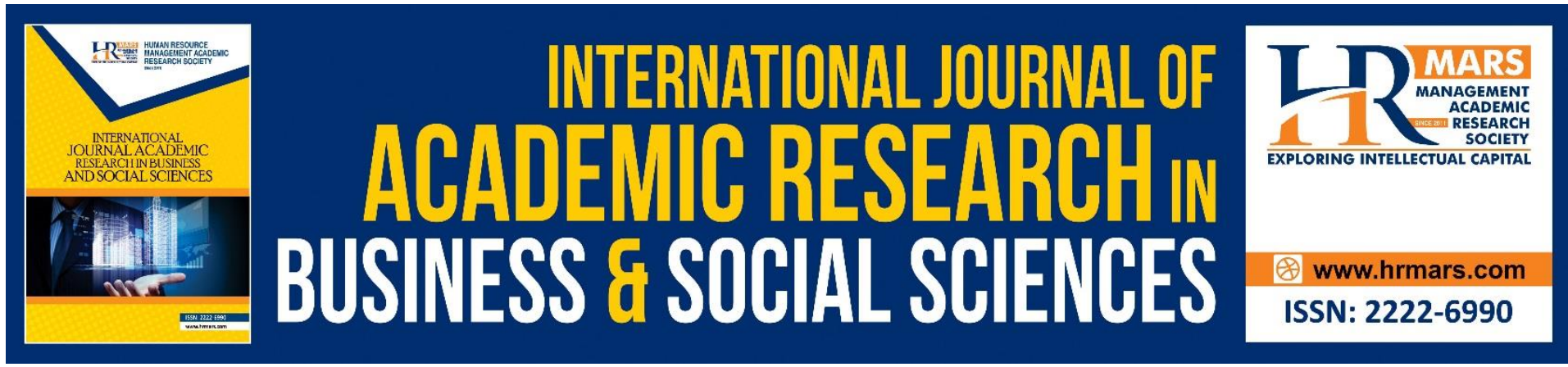

\title{
Evaluating Sexual Harassment against Female Workers in Higher Institutions in Anambra State, Nigeria
}

\author{
${ }^{1}$ Elizabeth Ifeoma Anierobi, ${ }^{2}$ Chukwuemeka E. Etodike, ${ }^{3}$ Vivian \\ Ngozi Nwogbo, ${ }^{1}$ Nkechi Uzochukwu Okeke \& ${ }^{3}$ Mary Nneka \\ Nwikpo \\ ${ }^{1}$ Department of Educational Foundations, Nnamdi Azikiwe University, Awka - Nigeria, \\ ${ }^{2}$ Department of Psychology, Nnamdi Azikiwe University, Awka - Nigeria, ${ }^{3}$ Department of \\ Education Management and Policy, Nnamdi Azikwe University, Awka - Nigeria
}

Email: ei.anierobi@unizik.edu.ng

\begin{abstract}
Sexual harassment like any negative job antecedents is one of the workplace vices which organizations attempt to checkmate in order to create conducive atmosphere for employees to thrive. In Nigeria, lack of legislative efforts and enforcement of extant laws have increased vulnerability. This study therefore attempts to evaluate the incidence and the impacts it may have on the workers which most likely affect organizational efficiency and effectiveness. Using a descriptive design, the study evaluated patterns of sexual harassment, prevalence and consequences in higher institutions in Anambra State, Nigeria. The sample comprised 312 female workers from three higher institutions in Anambra State whose ages ranged from $23 y r s$ and mean age of 37.50yrs and standard deviation of 2.40. Data were collected with the aid of 31-item questionnaire. Reliability of the instrument was ascertained at determined Cronbach alpha coefficient of 0.71 . The result of descriptive analysis revealed the prevalence of sexual harassment is high among female workers at $69.4 \%(X=3.9)$ with verbal sexual harassment being the most common type at $73.7 \%$ prevalence. Job insecurity was identified as the leading consequences of sexual harassment in the views of the female workers at $67.2 \%(X=3.4)$ among other consequences. Considering the job outcomes of sexual harassment of female workers in the workplace, it is recommended that organizational climate in education sector be protected by legislative enablement to create a gender free working environment for thriving of both males and females especially females who are the common victims of sexual harassment in this part of the world while prosecuting reported cases.
\end{abstract}

Keywords: Female Workers, Gender, Higher Institutions, Sexual Harassment, Working Environment 


\section{Introduction}

Sexuality is part of human life and existence. Ideally, sexual relationship should be mutual and between two adults, who consented without any form of coercion (Haruna et al., 2016).). When a sexual activity is as a result of intimidation of any sort, it becomes worrisome and an infringement to the individual's human right (Ramakrishnan, 2019) and this intimidation into unsolicited sexual activity usually puts the victim at a disadvantaged position for lack of consent (Cassino \& Besen-Cassino, 2019). Shaw et al. (2018) contended that in the workplace, sexual harassment is a serious crime with grievous cost to the victims, co-workers and the organization. This attribute makes sexual harassment in the workplace a much talked about organizational vice outside inherent job factors. In Nigeria, the organizational climate may not have aided harassment-free workplace due many industry related problems which are not unconnected to institutional corruption (Ezeh \& Etodike, 2016), uncontrolled abusive relationship between superiors and their subordinates in most public organizations (Ezeh et al., 2018), high levels of incivility among workers (Etodike \& Ezeh, 2017) and most importantly the prevailing organizational climate (Joe-Akune et al., 2018) in Nigerian higher institutions. Many female workers die in silence than report sexual harassment for the fear of losing their jobs due to the growing unemployment rate in Nigeria (Etodike et al., 2018) and this reduces workers involvement in the work (Joe-Akunne, 2018) and reduces organizational effectiveness (Shaw et al., 2018) due to the emotional, financial and social cost of sexual harassment (Haruna et al., 2016). In most cases, sexual harassment creates job insecurity among victims as an outcome of leader-member relationship or member-member relationship (Ezeh et al., 2017).

Sexual harassment is an organizational vice with unpalatable organizational outcomes including ineffectiveness, indifference, low job involvement and general poor citizenship behaviour towards the organizational members and the organization. Serious incidences of sexual harassment may be precursors to tarnishing organizational image, their integrity and the confidence of the public towards such organizations. It also leads to loss of job on the part of the employees and emotional trauma when it is constantly experienced by a hapless employee without being addressed. In some cases, it may lead to organizational anticlimax. These negative antecedents affect the job, the employees as well as the employers and the organization in whole and thus; make sexual harassment a contentious issue in the organization.

\section{Problem/Gap in literature}

Sexually harassment wherever it is found is problematic as most often it is perpetrated by superiors against subordinates or between people of uneven status with one capable of taking advantage of the other or willing to exploit the other's vulnerability as inferior (Sadler et al., 2018). Despite its devastating consequences, most literature in tertiary institutions were devoted to teacher-student sexual harassment with little evaluation into the harassment trend experienced by other female folk in the tertiary institutions such as female workers. Like female students, female workers are also targets of sexual harassment and exploitation (Oche et al. 2020). Many studies in sexual harassment in higher institutions of learning have neglected the fact that female workers are equally targets and victims of sexual harassment. 


\section{Objectives of the Study}

Against backdrop above, the current evaluation is aimed to:

i. The prevalence of sexual harassment among female workers in higher institutions of learning in Anambra State.

ii. The commonest type of sexual harassment among female workers in higher institutions of learning in Anambra State.

iii. The leading consequence of sexual harassment among female workers in higher institutions of learning in Anambra State.

\section{Review}

\section{Human Sexuality and Sexual Harassment}

Human sexuality is not deniable as it manifests in all we do. Ideally, sexual proposal are made by either males or females but accepting any form of sexual activity or gestures without coercion or intimidation gives the individual an opportunity to flow along with the partner in relationship, otherwise, it becomes harassing to the individual. Since civilization, individuals have inalienable rights to accept or decline sexual overtures from the opposite sex or same sex in cases of gay- lesbian-bisexual-transgender (GLBT).

The right to accept or reject sexual overtures is like other human rights and it equally extends to the workplace irrespective of its composition of authority and contextual circumstances (Shaw et al., 2018). In most circumstances in the workplace; whether a male or a female have the will to decline any form of relationship overtures may well be dependent on organizational climate and extant industry laws and the laws of the State or Country which protects the citizenry especially ones providing protection for women against all forms of discrimination, harassment and exploitation. According to Haruna et al. (2016), the position of the law in such case is not usually well defined in the Nigerian context and thus creates a safe haven for offenders. This situation makes sexual harassment a recurring decimal in the workplace and one which organizations should be wary of, if they must be successful.

Sexual harassment is perceived as unwelcome sexual advances and invitation to activities which take the power of choice and free will from the victim while infringing on their fundamental human right (Burn, 2019). For instance, if someone that is seen as a superior throws the weight of the high position to take sexual advantage of the subordinates in order to release benefits that is officially due to the victim, such scenario could be seen as a clear instance of sexual coercion. In other words, sexual harassment occurs when an individual experiences sexual advances and other forms of sexual behaviours without given one's consent. It was observed that the males are usually perpetrators of sexual harassment while the females are mostly the victims (Akinfala \& Tunde, 2017). Although, any person can be perpetrator or victim, one can assert that sexual harassment is a form of gender-based violence mostly against the female folk (Bondestam \& Lundqvist, 2020).

Sexual harassment could take many forms ranging from physical forms, verbal forms and nonverbal forms (Kahsay et al., 2020). Physical form of sexual harassment occurs when there is an unwanted and unwelcomed bodily contact with the victim such as embarrassing touch, kissing, cuddling, deeds, and actions, to behaviours of sexual nature. Verbal form of sexual harassment is experienced through utterances, discussions, cracking of jokes of a sexual nature that make the target feel uncomfortable and harassed. Non-verbal form of sexual harassment results from gestures, sending of symbols and nudes, staring to seduce and 
exposing one's nude to the target individual. Hersch (2015) aligned with the above forms of sexual harassment while pointing out that sexual harassment includes a wide range of behaviors, from glances and rude jokes, to demeaning comments based on gender stereotypes, to sexual assault and other acts of physical violence. It was shown that different forms of sexual harassment against women include the following: inappropriate sexual comments, unwanted touching of female students' breasts, tapping of the female students' buttocks, and enticing of female students with high scores for sex (Onoyase, 2019). Similarly, Oni et al. (2019) observed that: unwanted touching, unwanted fondling, unwanted sexual advance, sex-related jokes, sex-related insults, unwanted sexual gestures and unwanted sexual oriented text messages, letters and phone calls are forms of sexual harassment against female folks.

Sexually harassing behaviours are specified into three categories namely: gender harassment, unwanted sexual attention and sexual coercion (National Academies of Sciences, Engineering, and Medicine (NASEM), 2018). Gender harassment includes verbal and nonverbal behaviors that are targeted at making the victim feel inferior based on one's gender. Unwanted sexual attention includes verbal or non-verbal unsolicited sexual advances, directed at the victim as a person. Sexual coercion occurs when professional or educational treatment one is entitled to is conditioned in such a way that the person might not get them except by yielding to unwelcomed sexual activity. This becomes worrisome and problematic as sexual harassment denies the victim the right to choice and free will. Sexual harassment is like a canker which has eaten deep into the fabrics of the society. Literature indicated that it occurs in every society, organizations, workplace and institutions across the globe (Oni et al., 2014). In Nigeria, cases of sexual harassments and escapes abound in almost all walks of life including the higher institutions even with the recent cases in the banking sector and some of the churches (Onoyase, 2019). In most Nigerian higher institutions, sexual harassment seems to be more prevalent than school cultism in higher institutions (Ahmed \& Tijani, 2019; Onoyase, 2019). Victims of sexual harassment in every sector especially in higher institutions are mostly females while males are mostly the perpetrators. Sheriff and Garba (2010) averred that male lecturers see it as one of the exploits of office and male students see it as part of campus life.

To give credence to this, many cases of sexual harassment against female students in Nigerian higher institutions abound in literature. Some of the cases were male lectures against female students or male students against female students. To confirm sexual harassment trend in higher institutions of learning, social media trended on many high profile cases of sexual harassment against female students in some of the Universities in Nigeria between 2018 and 2020. For instance there was a popular case of a female student and a male professor in Obafemi Awolowo University, Ile-Ife (Onoyase, 2019) over sex for grade. Moreso, another lecturer was suspended in same university over alleged sexual assault (Punch, February 5 , 2020). There was also the suspension of Academic Staff Union of Universities' Branch Chairman of Ambrose Alli University, Ekpoma, Delta State, Nigeria (Punch, March 19, 2019) over sex for grade. This seems to underscore the reason for the engagement of investigative journalism on sexual harassment in some of the universities in Nigeria. Their findings trended on media exposing many lecturers and professors alike (Adebayo, 2020). Little wonder, Imonikhe, et al. (2012) posited that some male lecturers use sex for grade as baits for luring female students to give in to their sexual advances. 
Research has revealed that there is prevalence of sexual harassment of female students of tertiary education in Nigeria. For instance, in Taraba State, Nigeria, an empirical study found that there is prevalence of sexual harassment against female students with no substantial difference among the participants in the universities, polytechnics and colleges of education used for the study (Onoyase, 2019). Similarly, in a study on sexual harassment of female undergraduates in the Anambra State of Nigeria, Okeke (2011) found that majority of the respondents had experienced one form of sexual harassment or the other, such as inappropriate touch, gestures and inappropriate jests expressed around them. Omonijo et al. (2013) surveyed the prevalence of sexual harassment on three religious-inclined private universities in the Ogun-State, South-West Nigeria and revealed that the majority of female students in the three institutions had become victim of sexual harassment on campus. Apart from sexual harassment in institutions against female students, female workers also fall victims of it in their workplaces.

\section{Workplace Sexual Harassment}

Workplace sexual harassment against female workers is not only unethical but it is also globally condemned. This is because sexual harassment against female workers has many consequences and negative effects on both the victim and organization where it occurs (Akinfala \& Tunde, 2017). Ideally, workplace environment, especially higher institutions, should be structured in such a way that will portray conduciveness and free from any form of threats to foster maximum commitment upon which quality performance leverages and thrives. Employees' performance is critical to the survival and optimization of any organization, higher institutions inclusive. Deductively, one can assert that the work performance of female workers in higher institutions is germane towards the survival and progress of the institution and should not be jeopardized through sexual harassment.

Research has shown that generally, sexual harassment against women has many consequences ranging from negative effects on the woman as an individual to their work productivity (Idris et al., 2016). Similarly, Lindquist and Mckay (2018) reported decreased job satisfaction, organizational commitment, productivity, and increased work attrition among their respondents on consequences of sexual harassment. According to the study carried out in the legal sector, Aina-Pelemo et al. (2019) found that low performance, psychological and health challenges are among the consequences of sexual harassment against female workers. No wonder, Idris et al. (2016) found that most female employees in some selected organizations in Kogi State, Nigeria perceived sexual harassment as highly embarrassing, offensive while some perceive it as normal and solicited for. Empirical evidence also revealed prevalence of sexual harassment against female teachers in primary and secondary schools in Idah local government, Kogi State (Idri et al, 2016). In another study conducted with banking sector, Akinfala and Tunde (2017) revealed that the rate of sexual harassment against female workers is high in banking sector in Nigeria. Similarly, Amos (2016) found that women in the police sector also experience sexual harassment in their workplace especially when it comes to the matter of posting to duty posts. Aligning to the above findings, Adetutu and Iseoluwa (2020) confirmed the prevalence of sexual harassment in workplaces in Nigeria pointing out the banking, medical, police, and legal sectors. Sexual harassment against female workers in higher institutions might not differ in forms, prevalence and consequences from those experienced by female students in higher institutions in Nigeria. 
In order to curb the menace of sexual harassment against the female gender in Nigeria higher institutions, a bill was passed in 2016 to prohibit sexual harassment in Tertiary Educations which stipulated a 5 year jail term without an option of fine for culprits of sexual harassment (Adetutu \& Iseoluwa, 2020). Similarly, the Nigerian Senate passed a bill on sexual harassment against the female (Adebayo, 2020). Despite these and other like measures taken to curb the ugly act, Bello (2020) observed that sexual harassment against the females still persist in work places in Nigeria and Anambra State is not an exception. In the glaring empirical evidence of sexual harassment against female workers in many sectors in Nigeria, there is no documentation of cases of sexual harassment against female workers in higher institutions in Anambra State, Nigeria. This gap in literature prompted this study. The findings of the study should provide empirical documentation for future researches on similar study. This study, therefore, sought to examine the prevalence, forms, and perception and consequences of sexual harassment against female workers in higher institutions in Anambra State and to further provide the way forward in preventing the canker from further spread. To give direction to this study, five research questions were posed.

\section{Consequences of sexual harassment in the organization}

Generally, victims of sexual harassment suffer significant psychological effects, including anxiety, depression, headaches, sleep disorders, weight loss or gain, nausea, lowered selfesteem and sexual dysfunction. In relation to work, they experience job-related costs as well: from job loss, decreased morale, decreased job satisfaction to irreparable damage to interpersonal relationships at work. In the higher education setting, it can effect students indirectly and intensify the campus atmosphere for students, teachers and other workers. There are always physical and psychological distress associated with sexual harassment leading to a tense and unproductive working and learning environment.

\section{Method}

Design - The study adopted descriptive survey design. The choice of this design was based on the fact that the study sought to evaluate the existing conditions of sexual harassment against female workers in higher institutions in Anambra State.

Participants - The study covered 3 higher institutions in Anambra State, one university, one polytechnic and one college of education. The population of the study comprises of 1,680 female workers in the three institutions studied. The sample size comprised of 312 female workers who volunteered to participate in the study, 104 from each of the institutions. The sample comprised 312 female workers from three higher institutions in Anambra State whose ages ranged from 23yrs and mean age of 37.50yrs and standard deviation of 2.40. The participants were sampled using multi-stage sampling technique which involved purposive, cluster and simple random sampling techniques. Purposive sampling was used to select the institutions; cluster sampling was using to select their faculties, departments and units whereas simple random sampling was used to select participants from their departments.

Measure - A structured questionnaire titled Sexual Harassment against Female Workers Questionnaire (SHFWQ) was used in eliciting responses from the respondents. The questionnaire contained 31 items with five clusters (prevalence: 3 items, forms: 3 items, perception: 6 items, consequences: 10 items and preventive measures: 10 items) to address each of the research questions. The response system of the questionnaire is on a four point 
Likert scale of strongly agreed, agreed, disagreed and strongly disagreed weighing 4, 3, 2, and 1 respectively. The questionnaire was validated by three expertsin the Faculty of Education, Nnamdi Azikiwe University, Awka, Nigeria. The reliability of the instrument was determined through trial testing the instrument on 50 female workers in a higher institution in Enugu, Nigeria which is outside the study area. Cronbach Alpha was employed in determining the internal consistency of the instrument and an alpha coefficient of 0.71 was obtained which is considered high and reliable for use.

Procedure - The study started with a pilot study to ensure the instruments for the study are reliable measure of the construct. Consequently, responses of 30 female workers from 3 tertiary institutions (Nnamdi Azikiwe University Awka, Federal Polytechnic Oko and Federal College of Education Umunze) all in Anambra State were elicited with the help of NYSC members as research assistants. The researchers together with the research assistants visited the institutions and gave out the questionnaire to participants who were willing to be part of the study having introduced themselves as researchers carrying out empirical inquiry. The questionnaire was prepared in a booklet and was hand-distributed to the participants. The participants were given both oral and written instruction on how they may fill in the items in the questionnaire. The participants were assured of the confidentiality of their responses as there is no right or wrong answers, since the inquiry is only for an academic purpose. Filling of their responses to the item questions took each of the respondents about 19 minutes. Afterwards, the researcher collected back the filled questionnaire from the respondents. From the data, 37 questionnaire booklets were distributed, 32 were collected back while 30 were valid. After collecting the filled questionnaire, they were sorted and only the valid ones were coded in excel spread sheet for analysis. Analysis included descriptive evaluation of participants' responses

\section{Results}

Table 1: Frequency and percentage of the prevalence of sexual harassment against female workers in higher institutions in Anambra State

\begin{tabular}{ccccc}
\hline $\mathrm{S} / \mathrm{N}$ & \multicolumn{1}{c}{ Item } & Response & Frequency & Frequency $\%$ \\
\hline 1 & In my workplace, I & Never & 0 & 0 \\
& experience sexual & Sometimes & 217 & 69.4 \\
& harassment & Often & 95 & 30.6 \\
& & 312 & 100 \\
\hline
\end{tabular}

Table 1 indicates that the prevalence of sexual harassment among female workers in 3 selected higher institutions in Anambra State is high at $X=3.9$. With 217 (69.4\%) participants agreeing to have experienced sexual harassment at sometimes and 95 (30.6\%) experiencing the behaviour often, the prevalence rate is extremely high. 
Table 2: Forms of sexual harassment experienced by female workers in higher institutions in Anambra State

\begin{tabular}{ccccc}
\hline $\mathrm{S} / \mathrm{N}$ & Item & Response & Frequency & Frequency $\%$ \\
\hline 1 & Forms of sexual & Physical & 50 & 16 \\
& harassment & Verbal & 230 & 73.7 \\
& & Non-verbal & 32 & 10.3 \\
& & 312 & 100 \\
\hline
\end{tabular}

Table 2 identifies 3 major forms in which participants have experienced sexual harassment in higher institutions. Participants' analyzed responses indicated that of sexual harassment experienced occurs as verbal harassments at $73.7 \%$ in relation to other forms such as physical at $16 \%$ and non-verbal at $10.3 \%$.

Table 3: Mean and standard deviation scores of consequences of sexual harassment on female workers in higher institutions in Anambra State

$\mathrm{S} / \mathrm{N}$ Consequences of sexual harassment on female workers $X \quad$ SD Remarks

Sexual harassment affects me in the following ways:

1. It affects my self-esteem negatively

2.550 .089 Agreed

2. It makes me feel bored coming to work

3. It makes me feel intimidated

$2.57 \quad 0.089$ Agreed

4. It negatively affects my work performance 3.01

5. It makes me feel unsecured in my workplace

6. It makes me feel emotional torture

2.580 .089 Agreed

7. It makes me avoid male colleagues

3.330 .084 Agreed

8. It makes me feel like a cheap prey

2.640 .089 Agreed

9. Refusal made me loose official benefits

10. It arouses me sexually Grand mean

2.510 .089 Agreed

2.250 .090 Disagreed

2.73

Table 3 shows that consequences of sexual harassment among female workers in higher institutions among other things include: negative esteem, boredom, intimidation, low output, job insecurity, emotional torture, avoidance of male colleagues, feeling cheap and loss of legitimate benefits. However, job insecurity remains the greatest consequence of sexual harassment at $67.2 \%(X=3.36)$.

\section{Discussion}

The study evaluated the responses of 312 female worker participants regarding their experiences about sexual harassment in higher institutions in Anambra State, Nigeria. He growing concern of female sexual harassment in high institution in recent time motivated the study. Thus, a cross sectional survey was carried out and analyzed using descriptive statistics and findings reveal that the prevalence rate of female worker sexual harassment in higher institutions is high and indication that the researchers' suspicion is correct. The finding is consistent with Oche et al. (2020) who identified the prevalence of sexual violence among female employees in Sokoto Metropolis in North-West Nigeria. Also, the finding is in consonant with Haruna et al. (2016) who also established high prevalence rate of sexual harassment of female employees in selected organizations in Kogi State, Nigeria. Their finding 
in support with the current study is an indication of high prevalence of sexual harassment in Nigerian work organizations.

Although, more focus is usually given to sexual harassment of female students in higher institutions; the current study has thus increased the focus of attention not just on students alone but more to female workers in higher institutions. With many sexual scandals in the workplace now all over the local newspapers; it is high time legislative effort is made to promote female workers from sexual harassment in their places of work especially those them working in institutions of higher learning. Like every other workplace vice, sexual harassment has negative antecedents to the organization. It negatively affects leadermember and member-member relationship in the organization which in turn negatively affects organizational effectiveness. It affects citizenship behaviour as much as it counterproductive making it difficult for members' productive participation in decision making (Ike et al. 2017). When sexual harassment is not addressed in the workplace, it becomes a form of exploitative injustice which further constitutes occupational stress to workers (Ezeh \& Etodike, 2017).

Equally, participants indicated that they are more sexually harassed verbally than any other type of sexual harassment. Verbal harassment sexually or otherwise is a going trend in the workplace mostly because it is difficult to investigate and it is a subtle form of abuse which can go unnoticed without the eyebrows of the public. In the workplace, derogatory sexual remarks are common with intent to arouse the interest of the person or sexually mock them into becoming uncomfortable till they decide to yield to proposed sexual advances. Verbal sexual harassment may be regulated with proper assertiveness training; this is because assertiveness training has been linked with higher levels of self-esteem and confidence (e.g. Etodike et al. 2017) which are required by the victims to cope with the sexual harassment. This implies that all the selected female workers in higher institutions in Anambra State have experienced one form of sexual harassment or the other irrespective of their age or cadre. This finding aligns with the assertion of Oni et al. (2014) that sexual harassment occurs in every society, organizations, workplace and institutions across the globe. This finding also collaborates with Sheriff and Garba (2010) which construed those male lecturers see it as one of the exploits of office. Sexual harassment against female workers in higher institutions in Anambra State was found to have negative consequences on the victims and the organization. This finding agrees with Akinfala and Tunde (2017) that sexual harassment against female workers has many consequences and negative effects on both the victim and organization where it occurs. Ideally, workplace environment, especially higher institutions should be structured in such a way that will portray conduciveness and free from any form of threats.

Furthermore, the finding of this study indicated that job insecurity is the greatest consequence of sexual harassment among female workers as supported by Idris, et al. (2016); Lindquist and Mckay (2018) and Aina-Pelemo et al. (2019) emphasizing that the effect of sexual harassment against women is not only on the woman as an individual but on also on her work productivity. The study also found that majority of the participants perceive sexual harassment against female workers in higher institutions in Anambra State as embarrassing and offensive while a smaller percentage of the participants feel indifferent about sexual and others perceive it as normal and solicited for. The finding of this study aligns with Idris, et al. (2016) that majority of their participants(female employees in some selected organizations in 
Kogi State, Nigeria) perceived sexual harassment as highly embarrassing, offensive while some perceive it as normal and solicited for. The study also found that universities should put in check necessary measures and ensure their implementation towards curbing sexual harassment against female workers in higher institutions of learning in Anambra State. These measures will augment the measures stipulated by the Federal Government of Nigeria in fighting the ugly monster from our education system (Adebayo, 2020; Adetutu \& Iseoluwa, 2020).

\section{Implications of the Study}

Sexual harassment is workplace attitude equally experienced by female workers in higher institutions of learning. The prevalence trend is high probably because of poor legislative framework seeking to protect women and other vulnerable persons from exploitation especially in superior-to-subordinate relationship and even member to member daily interaction in the workplace. The discreet and subtle nature of verbal sexual harassment may have made it the commonest and the most preferred method of sexual harassment against female workers. There are costs which follow sexual harassment including emotional, financial and interactional costs. Besides, employees, their jobs and organizations may be endangered following incidences of sexual harassment and this may threaten employees jobs leading to job insecurity and voluntary turnover.

\section{Conclusion}

Through the findings of this study, it was concluded that there is prevalence of sexual harassment against female workers in higher institutions in Anambra State. Sexual harassment against the female workers takes many forms ranging from gender harassment, unwanted sexual attention to sexual coercion, and of course, the victims perceive the hideous act as embarrassing, offensive with only a few considering it as normal, solicited and indifferent. The victims agreed that sexual harassment affects them negatively except for their work performance. Finally, the victims agreed that sexual harassment can be prevented through among others, prosecuting the culprits no matter their ranks in the institution.

\section{References}

Adebayo, B. (2020). Nigerian senate passes sexual harassment bill. CNN July 08, 2020. https://edition.cnn.com/2020/07/08/africa/nigeria-sexual-harassment-bill/index.html

Adetutu, A., \&lseoluwa, A. (2020). The trajectory of Nigerian law regarding sexual harassment in the workplace.AJLHR 4 (2), 1-9

Ahmed, I., \& Tijjani, H. (2019). A study of sexual harassment in six selected states owned colleges of North Eastern States of Nigeria. International Journal of Innovative Research and Advanced Studies, 6(5), 100-108.

Aina-Pelemo, A. D., Mahanathan, M. C., Kulshrestha, P., \&Aina, I. T. (2019). Sexual harassment in the workplace: Case study of the legal sector. Journal of Law, Policy and Globalization 86, 121-137.

Akinfala, F. F., \&Tunde, K. (2017). Sexual Harassment as a Predictor of Organisational Outcomes.African Journal for the Psychological Study of Social Issues, 20(1), 60-73.

Amos, I. O. (2016).Factors Affecting Female Police Officers' Performance in Akure Community, Ondo State, Nigeria.Research on Humanities \& Social Sciences, 6(3), 42-52. 
Bello, P. O. (2020). Combating sexual harassment in ivory tower in Nigeria: Mixed feelings. Bangladesh e-Journal of Sociology 17 (1), 173-189

Bodestam, F., \&Lundqvist, M. (2020). Sexual harassment in higher education: A systematic review. European Journal of Higher Education https://doi.org/10. $1080 / 21568235.2020 .1729833$

Burn, S. M. (2019).The psychology of sexual harassment.Teaching of Psychology 46 (1), 96103. SAGE. https://doi:10.1177//0098628318816183

Cassino, D., \& Besen-Cassino, Y. (2019). Race, threat and workplace sexual harassment: The dynamics of harassment in the United States, 1997-2016. Gender, Work \& Organization, 26(9), 1221-1240.

Etodike, C. E., \& Ezeh, L.N. (2017). Perceived Workplace Incivility: A predictive Study of Emotional Regulation and Marital Status among Administrative Staff of Nigeria Universities. Scholars Journal of Economics, Business and Management,4(8),504-508. http://saspjournals.com/sjebm.DOI: 10.21276/sjebm

Etodike, C.E., Ezeh, L.N., Ogbeide, Davies E.O. \& Ike, P.R. (2018). Typical Solution to the Unemployment Problems in Nigeria: The Convergence Utility of the Entreprenuership Models. European Journal of Human Resource Management Studies 1(2), 130-138. http://www.oapub.or/soc DOI: 10.5281/zenodo.1253337

Etodike, C. E., Ike, P. R., \& Chukwura, E. N. (2017). Assertiveness Training: Academic Performance and Self-Esteem among College Students in Selected Rural Areas. International Journal for Psychotherapy in Africa 2(1), 7-13.

Ezeh, L. N., \& Etodike, C. E. (2016). Corruption in Nigeria organizations: Theories \& implications. In Proceedings of Annual Scientific Conference of Nigeria Psychological Association (NPA), held at Nnamdi Azikiwe University Awka, Nigeria, $11^{\text {th }}-14^{\text {th }}$ Oct. 2016

Ezeh, L. N., \& Etodike, C. E. (2017). Work overload and distributive injustice as predictors of occupational stress among Health workers. International Journal in Management and Social Science, 5(7), 537-547. http://www.ijmr.net.in. ISSN:2321-1784.

Ezeh, L. N., Etodike, C. E., \& Chukwura, E. N. (2018). Abusive Supervision and Organizational Cynicism as Predictors of Cyber-Loafing among Federal Civil Service Employees in Anambra State - Nigeria. European Journal of Human Resource Management Studies, 1(2), 19-36. http://www.oapub.org/soc DOI: 10.5281/zenodo.1172162.

Ezeh, L. N., Etodike, C. E., \& Ike, P. R. (2017). Employee Turnover Intention: A predictive Study of Organizational Politics, Leader-Member Exchange and Job Insecurity. International Journal of Current Advanced Research, 6(2), 2294-2300. www.journal icar.org

Haruna, I., Joseph, A., Samson, A., \& Aye Gabriel, A. (2016). Analysis of the causes and effects of sexual harassment on the performance of female employees in some selected organizations in Kogi state Nigeria. Intl J Democrat Develop Studies, 2, 31-9.

Hersch, J. (2015). Sexual harassment in the workplace.IZA world of Labour.Retrieved from https://wol.iza.org. doi:10.15185/izawol.188

Idris, H., Adaja, J., Audu, S., \& Aye, G. A. (2016). Analysis of the causes and effects of sexual harassment on the performance of female employees in some selected organizations in Kogi State, Nigeria.International Journal of Democratic and Development Studies 2 (2), 31-39.

Ike, P. R., Ezeh, L. N., \& Etodike, C. E. (2017). Employee Participation in Decision Making: A correlate of Employee Citizenship Behaviour and Counterproductive Workplace 
Behaviour. Journal of Academic Research in Business and Social Sciences, 7(7), 934-948. http://dx.doi.org/10.6007/ IJARBSS/v7-i73179 DOI: 10.6007/IJARBSS/v7-i73179

Imonikhe, J., Aluede, V. O., \&Idogho, P. (2012).A survey of teacher and students' perception of sexual harassment in tertiary institutions of Edo State, Nigeria.Journal of Asian Social Science, 8 (1), 268-273.

Joe-Akunne, C. O., Ogbeide, Davies, E. O., \& Etodike, C. E. (2018) Employee Involvement: A Predictive Study of Organizational Climate Dimensions among Private Sector Employees. Scholars Journal of Economics, Business and Management (SJEBM) 5(12), 131-139. http://saspjournals.com/sjebm DOI: 10.21276/sjebm.2018.5.12.6

Kahsay, W. G., Negarandeh, R., Nayeri, N. D., \&Hasanpour, M. (2020). Sexual harassment against female nurses: A systematic review. BMC Nursing 19:58, 1 12.https://doi.org/10.1186/s12912-020-00450-w

Lindquist, C., \&Mckay, T. (2018). Sexual harassment experiences and consequences for women faculty in science, engineering and medicine.Policy Brief.RTI International.https://doi.org/10.3768/rtipress.2018.pb.0018.1806

National Academies of Sciences, Engineering, and Medicine. (2018).Sexual harassment of women: Climate, culture, and consequences in academic sciences, engineering, and medicine. Washinton, DC: The National Academies Press. doi:https://doi.org/10.17226/24994.

Oche, O. M., Adamu, H., Mallam, S. A., Oluwashola, R. A., \& Muhammad, A. S. (2020). Assessment of knowledge, attitude and experience of sexual violence among female employees in Sokoto Metropolis, Northwest Nigeria. African Journal of Reproductive Health, 24(2), 164-175.

Okeke, C. M. A. (2011).Impact of sexual harassment on women undergraduates' educational experience in Anambra State, Nigeria. Seton hall University dissertation and theses (ETDs), paper 6. Available athttp://scholarship.shu.edu/cgi/viewcontent

Omonijo, D. O., Uche, O. C. O., Nwadiofor, K. L., Rotimi, O. A. (2013). A study of sexual harassment in three selected private faith-based universities, Ogun State, South-West Nigeria.Open Journal of Social Science Research 9, 250-263.

Oni, E. E., Adeniji, A. A., Osibanjo, Heirsmac, T. P. (2014). Impact of domestic abuse on female employees' productivity in the Nigerian workforce.European Scientific Journal 10 (26).

Oni, H. T., Tshitangano, T. G., \&Akinsola, H. A. (2019).Sexual harassment and victimization of students: A case study of a higher institution in South Africa. African Health Sciences 19 (1), 1478-1485. doi:10.4314/ahs.v19i1.21

Onoyase, A. (2019). Prevalence of Sexual Harassment of Female Students of Tertiary Education in Taraba State, North East Nigeria: Implications for Counselling. International Journal of Higher Education, 8(1), 77-83.

Punch, Nigeria. (2019). AAU suspends ASUU chair over alleged sexual harassment. Retrieved from https://punchng.com

Punch, Nigeria. (2020). Another OAU lecturer suspended for alleged sexual assault. Retrieved from https://punchng.com

Ramakrishnan, D. (2019). Sexual Harassment of Women at Workplaces: Legal Safeguards and Preventive Mechanisms in India. International Journal of Research and Analytical Reviews, 6(2).

Sadler, A. G., Lindsay, D. R., Hunter, S. T., \& Day, D. V. (2018). The impact of leadership on sexual harassment and sexual assault in the military. Military Psychology, 30(3), 252263. 
INTERNATIONAL JOURNAL OF ACADEMIC RESEARCH IN BUSINESS AND SOCIAL SCIENCES

Vol. 11, No. 2, 2021, E-ISSN: 2222-6990 @ 2021 HRMARS

Shaw, E., Hegewisch, A., \& Hess, C. (2018). Sexual harassment and assault at work: Understanding the costs. Institute for Women's Policy Research Publication, IWPR $B, 376$. 